V.S. Falshtynskyi ${ }^{1}$, Cand. Sc. (Tech.), Assoc. Prof., orcid.org/0000-0002-3104-1089,

R. O. Dychkovskyi ${ }^{1}$, Dr. Sc. (Tech.), Prof., orcid.org/0000-0002-3143-8940,

P. B. Saik ${ }^{1}$, Cand. Sc. (Tech.), Assoc. Prof., orcid.org/0000-0001-7758-1083,

V. H. Lozynskyi ${ }^{1}$, Cand. Sc. (Tech.), Assoc. Prof., orcid.org/0000-0002-9657-0635,

E. C. Cabana ${ }^{2}$, Cand. Sc. (Tech.), Assoc. Prof.
1 - National Mining University, Dnipro, Ukraine, e-mail: saik.nmu@gmail.com

2 - Scientific Research Institute of the Center of Renewable Energy and Energy Efficiency at St. Augustine University, Head, Peru, e-mail: ecaceresca@unsa.edu.pe

\title{
SUBSTANTIATION INTO "ROCK MASSIVE - UNDERGROUND GASIFIER” SYSTEM ADAPTABILITY OF SOLENOVSKYI SITE IN THE DONETSK COAL BASIN
}

Purpose. Research on stress-deformed state of rock massive around underground gasifier taking into account the change in the continuity of the roof rocks and the thermodynamic stresses in them.

Methodology. Conducting analytical studies was based on the accepted physical and mathematical models, for the development of which the rock massif movement theory of Professor A. V. Savostianov is adopted, reflecting the features of the rock strata behavior over the gasifier (stratification, the fractures and stratification cavities formation, layers movements relative to each other).

Findings. Multivariant calculations of the stress-deformed state of the rocks around the underground gasifier are performed with the establishment of the load diagrams parameters for the sub-layers of the massif, depending on geological, technological and temporal factors.

Originality. Dependencies of the underground gasifier bearing pressure zones distribution on the adjacent roof level of the coal seam were established, taking into account gasification channel length $(30$ and $60 \mathrm{~m})$ and the velocity of combustion face advance from 0.5 to $2.0 \mathrm{~m}$ /day. For the first time, dependencies representing the rock layers subsidence parameters in the underground gasifier roof from geomechanical factors, as well as thermal stresses along the gasification channel length and the velocity of combustion face advance, were obtained.

Practical value. A mathematical mechanism was proposed for the determination of stresses in various rock massif sections in case of borehole underground coal gasification in order to establish the conditions for the "Rock massive underground gasifier" system adaptability, taking into account geomechanical factors and thermal stresses along the gasification channel length. The obtained dependencies make it possible to predict the necessary velocity of the combustion face advance to ensure technological effectiveness of the gasification process.

Keywords: underground gasification, combustion face, rock massif, gasification channel, stress-deformed state

Statement of the problem. The implementation of borehole underground gasification technology into the coal-mining complex of Ukraine is impossible without taking into account the adaptation processes in the "Rock massive - underground gasifier" system. Among these processes, an important place is taken by the adaptive impermeability of the underground gasifier, which is associated with the geological criteria, physico-mechanical, structural and filtration properties of the rock and coal massif, as well as with the changes occurring in the rock strata with the coal seam gasification.

Analysis of recent research and publications. The occurrence of anomalous rock pressure zones with the combustion face advance and the affected area growth causes the formation of areas around the gas generator with different degrees of rocks fracturing [1]. The geomechanical parameters of the roof rocks behavior during the coal seam gasification are identical to the conditions of the coal extraction in longwall face $[2,3]$ and methane gas output from the gas-hydrate deposits [4],

(C) Falshtynskyi V.S., Dychkovskyi R. O., Saik P. B., Lozynskyi V.H., Cabana E. C., 2018 but the main difference is due to the behavior of the adjacent roof over the gasifier, which lower layer in the combustion face area is subjected to thermoelectromotive force varying in length $(h=0.15-0.4 \mathrm{~m})$ under the influence of high-temperature processes $(T=480-$ $\left.1250^{\circ} \mathrm{C}\right)[5]$.

Technogeneous fracturing of the massif in the case of unconventional methods of gas extraction causes roof rock shearing and spalling into cavities $[6,7]$ and forms an increased enclosing rocks permeability [8], which leads to the destabilization of the process and contamination of the environment [9].

In the course of laboratory and bench studies devoted to the elastic properties of formation under the influence of high temperatures, an uneven change in the rocks thickness in the lower layer of the adjacent roof along the gasification channel length has been established, which leads to an increase in the rocks volume by $1-5 \%$ of the initial one, with elasticity modulus changing by $5-18 \%[10]$.

Identification of previously unsolved parts of the general problem. According to the results of analytical and bench research, the world scientists have established the 
parameters of the "underground gasifier - rock massive" system adaptability, taking into account the roof rocks continuity changing over the combustion face [11-13], but without taking into account the thermodynamic stresses.

The purpose of this article is to justify "rock massive - underground gasifier" system adaptability, which takes into account the parameters of the rocks continuity change with the coal seam gasification and the thermodynamic stresses in them for the mining and geological conditions of the Solenovskyi coal mining site.

Description of the research methodology. To determine the areas and parameters of rock mass discontinuity at the BUCG, the calculations have been performed, similarity criteria for the rock massif formation, elements of the underground gasifier, the gasification process of the coal seam, taking into account the stratigraphic section of the characteristic wells and bench maintenance test set parameters have been established. Analytical studies were carried out with separation into layers by the lithological difference and rock massif thickness of the stratigraphic section. In the absence of high power rock bridges, the separation into rock layers is carried out from the coal seam (gasified) to the daylight area, in the case of rock bridges presence - from the seam to the hard layer.

Geology of the deposit. Preliminary selection of BUCG sites was carried out on the coal seams $\left(c_{9}^{2}, c_{6}^{1}\right.$, $\left.c_{6}, c_{5}^{1}, c_{5}, c_{4}^{3}\right)$ of the Solenovskyi coal-mining area confined to the Lower Carboniferous sediments of $\mathrm{C}_{1}$ multiple coal layers, taking into account the acceptability appraisal criteria for the underground gasification process [7]. When acceptability appraisal criteria for the sites were made, the largest coefficient of acceptability 0.87 was obtained by $2 \mathrm{~A}$ site in coal layer $\mathrm{c}_{5}$, where it was proposed to construct an experimental underground gasifier.

2A site is located on the coal field of Solenovskyi -1, 2, 3 of the Krasnoarmiiskyi coal-bearing territory in Donetsk region, adjoined the northeastern slope of the Ukrainian crystalline massif and extended along the southeastern side of the Donetsk ridge. The natural boundaries of the 2A site, represented with multiple coal layers $c_{6}, c_{5}^{1}, c_{5}, c_{4}^{2}$, are the Tersianskyi normal fault No. 1 down the pitch in the north, Muraviovskyi normal fault across the pitch from the south, and the Tersianskyi normal fault from the east.

Property extension down the pitch is $H=1362 \mathrm{~m}$, across the pitch is $S=686 \mathrm{~m}$. The total producing reserves of the multiple coal layers of 2 A site are $Z=2083.2$ thousand tons. The depth of coal seams occurrence is $H=60-285 \mathrm{~m}$, the power is $m=0.5-0.75 \mathrm{~m}$, angle of incidence is $\alpha=7-23^{\circ}$. The coal of the formation is represented with $G$ and $J$ brands. The filtration properties of the seam are characterized within $0.4-0.6 \mathrm{D}$ range, the enclosing rocks are $0.8-1.1 \mathrm{D}$.

The hydrogeological conditions of the site are relatively favorable. The site is isolated by tectonic faults down and across the pitch from the hydraulic connection with the overlying water-bearing formation. Waters are confined to strata of coals, limestones and sand- stones. Water-bearing horizon of Lower Carboniferous deposits are represented in formation-fractured type with a pressure surface. The pressure varies in the range from 49.35 to $71.90 \mathrm{~m}$. The coefficient of filtration is $K_{f}=0.0045-0.9140 \mathrm{~m} /$ day. Coefficient of water conductivity is $K_{m}=4.36-9.51 \mathrm{~m}^{2} /$ day. The expected fluid influx into the underground gas generator is $0.85-$ $4.7 \mathrm{~m}^{3} / \mathrm{t}$.

Taking into account that limestone and sandstone layers are limited with tectonic faults, only insignificant stocks of static waters are contained in limestone and sandstone of the roof [14].

Coal of $c_{5}$ layer of $J$ grade is black, simple structured, thin-layered, lying calm with the rocks falling in the northern and northeasterly directions at an $8-18^{\circ}$ angle with the outlet under the deposits $\left(h_{n}=75 \mathrm{~m}\right)$, decreasing in the disjunctive geological fault zone up to $14^{\circ}$. The calorific value of combustible fuel varies between 33.8 and $36.6 \mathrm{MJ} / \mathrm{kg}$, with an average value of $34.5 \mathrm{MJ} / \mathrm{kg}$. The lowest calorific value is $32.2 \mathrm{MJ} / \mathrm{kg}$. The detailed information is presented in Table 1.

The main roof and bottom of the layer are represented with alternating of sandy and irregular metal layers, and sandstone, and the adjacent roof of the layer predominantly with sandy shale of average hardness with a strength coefficient $f=4$. The main roof is represented with sandstone and sandy shale dense, of average hardness with a strength coefficient $f=5$, medium-broken (A2).

Directly under the layer is a sandy shale with the $0.1-0.2 \mathrm{~m}$ thickness, $f=2$. Below, the soil is represented mainly with irregular metal with $f=3-4$ strength coefficient, medium-tight. Irregular metal and sandy shales are a reliable aquaclude and will protect the combustion face from entering static water that is in the sandstone. The water-bearing formation of stratal-fracture type is a pressure head, with variable magnitude from 58 to $75 \mathrm{~m}$. The specific yield ranges from 0.001 to $0.067 \mathrm{l} / \mathrm{s}$, $K_{f}=0.0044-0.7200 \mathrm{~m} /$ day. Considering that there are no natural screens due to the up the pitch, fluid influx can be up to $0.84-1.70 \mathrm{~m}^{3} / \mathrm{t}$. The fluid influx will occur from the overlying horizon of $c_{5}^{1}$ and $c_{6}$ layers.

Results of the study. To calculate the stress-deformed state of the rocks, it is necessary to establish the parameters of the load diagram for the underworked seams of the massif, depending on geological, technological and temporal factors $[15,16]$. As a boundary condition we take the parameters of free and maximum rock layer subsidence of the immediate roof [17].

The selected mathematical apparatus under the BUCG conditions makes it possible to determine the lateral force $(Q)$, the moment $(M)$, cross-sectional

\section{Table 1}

Characteristics of coal reserves in the $c_{5}$ reservoir within the $2 \mathrm{~A}$ site

\begin{tabular}{|c|c|c|c|}
\hline $\begin{array}{c}\text { Stratification } \\
\text { depth, } \mathrm{m}\end{array}$ & $\begin{array}{c}\text { Thickness, } \\
\mathrm{m}\end{array}$ & $\begin{array}{c}\text { Density, } \\
\mathrm{t} / \mathrm{m}^{3}\end{array}$ & $\begin{array}{c}\text { Coal reserves, } \\
\text { thousand tons }\end{array}$ \\
\hline$\frac{75-280}{202}$ & $\frac{0.65-0.85}{0.8}$ & 1.25 & 487.5 \\
\hline
\end{tabular}


seams inclination $(\theta)$ and its descent $(y)$ [18]. Creation of mathematical models allows to solve the set issues with obtaining predictive results over an extended time frame [19].

The coal seam gasification temperature changes along the length of the gasification channel. The maximum temperature $\left(1050-1200{ }^{\circ} \mathrm{C}\right)$ is observed at the boundary of the oxidizing zone transition to the reducing one. Therefore, the combustion face rocks along the length of the gasification channel is subjected to different thermoelastic stresses, the same situation is observed in the affected area.

The stress-deformed state of the bottom bench of the adjacent roof is subjected to high temperatures, which leads to deformations and changes in the physical and mechanical properties of the rocks, depending on the thermal conductivity of the layer sections along the gasification channel length of the underground gasifier.

The heat exchange of the massif is carried out not only due to conduction, but also due to convection. This situation is justified by the stratification cavities formation in the roof of an underground gasifier and the presence of pores and fractures in it. The degree of influence of heat exchange convection $\left(\varepsilon_{k}\right)$ is determined by the presence of cavities in the rocks and their location, which in turn determines the thermal stress of the adjacent roof rocks. Therefore, to study the stress-deformed state of the roof of an underground gasifier it is necessary to take into account the changes in the elastic modulus $E_{\mathrm{T}}$ and the linear thermal expansion coefficient $\beta$. The elasticity coefficient varies depending on thermal effect correction factor influence $K_{t}=1.08-1.35$.

The primary causes of the rock layer destruction are normal loads, friction forces $\left(t_{f f}\right)$, moment of resistance and tangential stresses from shear forces, stresses from moment of resistance $(G)$, friction forces and tangential stresses from shear forces $\left(\tau_{s f}\right)$.

The stress-deformed state of rocks in the roof layer of the underground gasifier is determined with the main stresses $\left(G_{1}, G_{2}\right)$ and with the rock resistance test to simple compression (SPR). The condition for roof rocks destruction is the formula

$$
S P R>R_{c} \text { and } \tau_{\max }>R_{c},
$$

where $R_{\mathrm{c}}$ is the ultimate strength of the rock to simple compression, $\mathrm{t} / \mathrm{m}^{2}$.

There are no shear forces over the middle of the underground gasifier, normal loads are insignificant, and the condition of the rocks depends on the moment of resistance causing stress along $\left(\lambda G_{\mathrm{c}}, \lambda G_{r}\right)$ and perpendicular $\left(G_{c}, G_{r}\right)$ to the formation.

Due to its own weight and moment of resistance in the rock layer, through-the-thickness stresses are created perpendicular to the formation. According to the accepted physical model and the calculation scheme [18], the stresses in different sections of the rock layer are determined. The shear forces $Q_{x}$ and the moment of resistance $M_{x}$ are determined from the formula, $\mathrm{MPa}$ and $\mathrm{MPa} / \mathrm{m}$

$$
Q_{x}=B_{1 k} \cdot \sin \frac{\pi}{L} x+B_{1 k} \cdot \sin \frac{2 \pi}{L} x,
$$

$$
M_{x}=0.16 \cdot L \cdot\left[\begin{array}{l}
B_{1 k} \cdot\left(\cos \frac{\pi}{L} x+\sin \frac{\pi}{L} x-1\right)+ \\
+\frac{B_{2 k}}{2} \cdot\left(\cos \frac{2 \pi}{L} x+\sin \frac{2 \pi}{L}-1\right)
\end{array}\right] .
$$

The probability of vertical fissure in rocks development, contained in underground gasifier, depends on natural and man-caused factors. Due to the flexure of the rock layer, tension and contraction stresses arise, which lead to its movements along the formation [20, 21]. The magnitude of these movements is comparable with the value of the maximum subsidence and is 25$30 \%$ of them. The vertical fissure development is determined according to the rock deformations through horizontal displacements $N_{x}$, calculated for two adjacent sections according to the formulas, $\mathrm{mm}$

$$
\begin{gathered}
N_{x}=1.2 \cdot \frac{L^{2}}{K_{T} h_{l} \cdot f(k)} \times \\
\times\left(B_{1 k} \cdot \sin \frac{\pi}{L} x+\frac{B_{2 k}}{4} \cdot \sin \frac{2 \pi}{L} x\right) ; \\
\xi=\frac{\left(N_{2}-N_{1}\right)}{\left(x_{2}-x_{1}\right)} \cdot 1000,
\end{gathered}
$$

where $\xi$ is the horizontal deformations of the rock layer area $1 \mathrm{~m}$ long, $\mathrm{mm} / \mathrm{m}$.

The rock layer subsidence $Y_{x}$ in the given sections is determined from the formula, $\mathrm{mm}$

$$
\begin{gathered}
Y_{x}=0.4 \cdot \frac{L_{3}}{K_{T} h_{l}^{3} \cdot f(k)} \times \\
\times\left[B_{1 k} \cdot\left(\cos \frac{\pi}{L} x-1\right)+\frac{B_{2 k}}{8} \cdot\left(\cos \frac{2 \pi}{L} x-1\right)\right],
\end{gathered}
$$

where $f(k)$ is the rock deformation modulus that varies along the length of the layer during the transition from the bearing zone to the affected area and is determined from the formulas

$$
\begin{gathered}
F_{k}=F_{0} \text { at } 0<x<a ; \\
F_{k}=\left(E_{0}-E_{n}\right) \cdot \frac{f_{2}-x}{d_{0}}+E_{n} \text { at } a<x<f_{2} ; \\
F_{k}=E_{n} \text { at } f_{2}<x<L .
\end{gathered}
$$

In prototype and laboratory measurements of displacements, it was found that with a deformation $\varepsilon>$ $>5 \mathrm{~mm} / \mathrm{m}$, vertical fissures in the rock layers of the massif are observed [8, 12]. As a result of analytical studies, the geometric and physical parameters of the bearing zones of the percarbonic rock layer are determined. Bearing zones of anomalous rock pressure at the burned-out coal bed level, taking into account the length of the gasification channel and velocity of the combustion face advance, which characterizes the conditions of rocks continuity trouble of the adjacent roof are shown in Fig. 1.

The adjacent roof level of the coal seam $c_{5}$ is represented with sandy shales with $3.8 \mathrm{~m}$ thickness, which is 


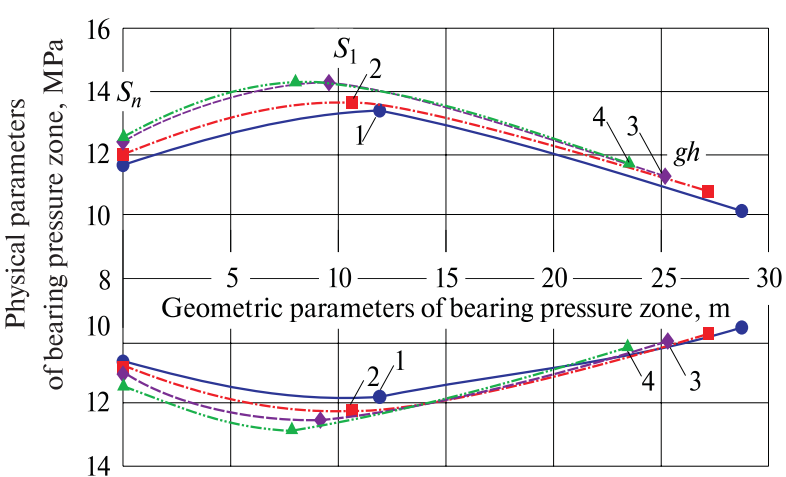

$a$

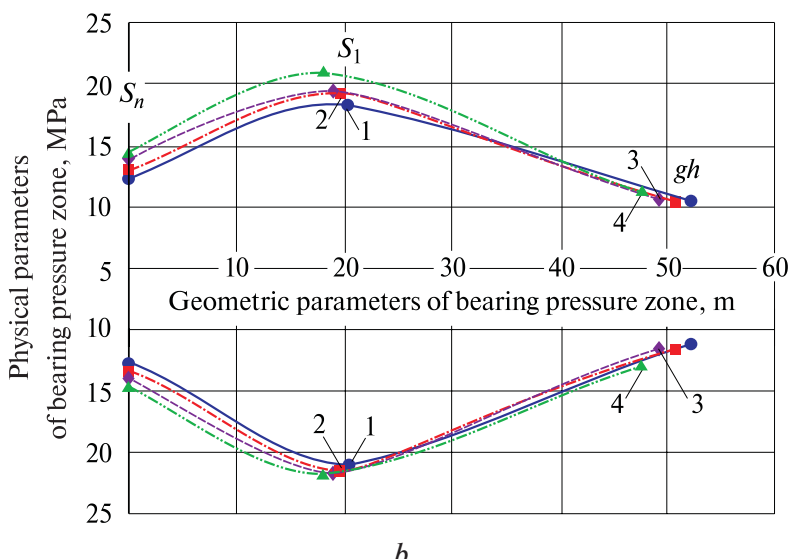

Fig. 1. Bearing zones of anomalous rock pressure at the adjacent roof level of the coal seam $c_{5}$, taking into account the length of the gasification channel and velocity of the combustion face advance:

$a-30 \mathrm{~m} ; b-60 \mathrm{~m} ; 1-2 \mathrm{~m} /$ day; $2-1.5 \mathrm{~m} /$ day; $3-$ $1 \mathrm{~m} /$ day; $4-0.5 \mathrm{~m} /$ day

stratified into two benches: the bottom bench is $1.8 \mathrm{~m}$ thickness and the upper one is $2.0 \mathrm{~m}$. The condition of the rock bands lying directly above the formation will depend on the loading of the main roof, high temperatures, ash capacity, the presence of rocks in the roof prone to heave, and the parameters of the stress-deformed state of the adjacent roof rocks.

The bottom bench of the adjacent roof will be more susceptible to thermodynamic stresses. It should be noted that the stresses in the rocks from the temperatures will be unequal due to the temperature difference along the gasification channel length. Subsidence of the rock layers of the roof taking into account the geomechanical factors and thermal stresses along the gasification channel length of the underground gasifier in the characteristic section ( $2 \mathrm{~m}$ from the combustion face) are shown in Fig. 2.

The subsidence and stresses in the bottom bench flexuring of the adjacent roof along the affected area are shown in Table. 2.

Analyzing the calculation data, presented in Table 2 and in Figs. 1, 2, it should be noted that with an increase in velocity of the combustion face advance, the bearing zone that appears ahead of the face at flexuring of the adjacent roof decreases $\left(d_{0}=11.9-7.8 \mathrm{~m}\right)$, and the load maximum increases to $13.34-14.2 \mathrm{MPa}$. At the same time, when the gasification channel length is $30 \mathrm{~m}$, the

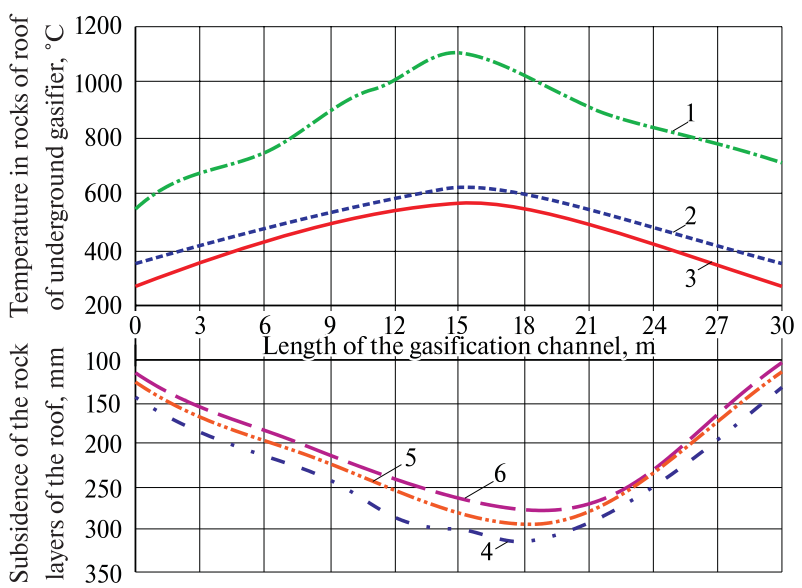

Fig. 2. Subsidence of the rock layers of the roof taking into account the geomechanical factors and thermal stresses along the gasification channel length of the underground gasifier at $2 \mathrm{~m}$ distance from the combustion face:

1, 2, 3 - parameters of temperature transfer along the length of the gasification channel at speeds of 0.5, 1.0 and $2.0 \mathrm{~m} /$ day productive workings velocity, respectively; 3,4 , 5 - the subsidence of the bottom bench of the roof rocks at $0.5,1.0$ and $2.0 \mathrm{~m} /$ day velocity of the combustion face advance, respectively

movements change insignificantly with a shift closer to the face. With a $60 \mathrm{~m}$ channel length with an increase in velocity of the combustion face advance, the geometric parameters of the bearing zone of the adjacent roof are reduced $\left(d_{0}=20.3-18.1 \mathrm{~m}, a=31.9-29.5 \mathrm{~m}\right)$, and the load maximum increases to $18.4-20.9 \mathrm{MPa}$. Man-caused vertical fissures above the gasification channel, which are directly related to the rock layers displacement are formed under these deformation conditions, in the range of $3.8-7.0 \mathrm{~mm} / \mathrm{m}\left(l_{\mathrm{g} . \mathrm{c}}=60 \mathrm{~m}\right)$ and $2.9-$ $6.0 \mathrm{~mm} / \mathrm{m}\left(l_{\mathrm{g} . \mathrm{c}}=30 \mathrm{~m}\right)$ in the rocks of the adjacent roof.

It should be noted that the adjacent roof broken condition developing during coal seam gasification is primarily related to the rock pressure, the secondary factor of vertical fissures developing in the adjacent roof is the uneven distribution of thermal stresses in it.

The adjacent roof rocks are not actively affected by the temperature field, the effects of thermal stresses on rock layers are insignificant or absent at all, which makes it possible to conduct analytical studies without taking into account the temperature coefficient $K_{t}$.

The deformation module for the main roof with $5.6 \mathrm{~m}$ thickness, under these conditions, is adopted without taking into account the temperatures, since under the conditions of the main roof occurrence, the temperature influence on the layer is small due to a decrease in the heat and thermal conductivity and the increase in the heat capacity of the rocks under the main roof. In the massif $E_{0}=1.81 .10^{4} \mathrm{MPa}$, over the worked out space $E_{h}=0.79 .10^{4} \mathrm{MPa}$. The calculation results of the critical deformations, subsidence and displacement of the main roof, taking into account the gasification channel length at the velocity of the combustion face advance, are presented in Table 3. 
Physical parameters of the bearing zones at bottom bench flexuring of the adjacent roof*

\begin{tabular}{|c|c|c|c|c|c|c|c|}
\hline \multicolumn{3}{|c|}{ Stresses, MPa } & \multicolumn{2}{c|}{ Subsidence, $\mathrm{mm}$} & \multicolumn{2}{c|}{ Displacements, $\mathrm{mm}$} & face advance, $\mathrm{m} /$ day \\
\hline $\mathrm{G}_{\mathrm{c}}$ & $\mathrm{G}_{\mathrm{p}}$ & $\mathrm{G}_{\text {от }}$ & above the face & $15 \mathrm{~m}$ from the face & above the face & $15 \mathrm{~m}$ from the face & \\
\hline 14.1 & 3.6 & 1.4 & 155.0 & 584.0 & 61.2 & 140.6 & 0.5 \\
24.9 & 7.9 & 3.1 & 226.0 & 695.0 & 165.0 & 219.3 & 1.0 \\
\hline 17.5 & 4.9 & 1.8 & 114.0 & 551.0 & 53.1 & 119.7 & 206.5 \\
\hline 26.9 & 8.4 & 3.5 & 203.0 & 592.0 & 149.0 & 110.0 & 2.0 \\
\hline 19.8 & 6.7 & 2.3 & 106.0 & 497.0 & 44.0 & 194.8 & \\
\hline 32.1 & 9.6 & 3.8 & 198.0 & 584.0 & 136.0 & & \\
\hline
\end{tabular}

* the values for the length of the gasification channel are $30 \mathrm{~m}$ in the numerator, in the denominator $-60 \mathrm{~m}$

Table 3

Critical deformation of subsidence and displacements of the main roof

\begin{tabular}{|l|c|c|c|c|c|c|}
\hline \multirow{2}{*}{$\begin{array}{c}\text { Type of deformations in the } \\
\text { main roof }\end{array}$} & \multicolumn{7}{|c|}{ Section considered from the face, $\mathrm{m}$} \\
\cline { 2 - 7 } & 10 & 10 & 15 & 20 & 25 & 30 \\
& 20 & 30 & 40 & 50 & 60 \\
\hline Deformations, $\mathrm{mm} / \mathrm{m}$ & 4.6 & 3.3 & 3.8 & 4.2 & 4.5 & 5.7 \\
& 189 & 270 & 362 & 448 & 521 & 618 \\
\hline Lowerings, $\mathrm{mm}$ & 272 & 396 & 474 & 563 & 629 & 710 \\
\hline Displacements, $\mathrm{mm}$ & 75.2 & 117.4 & 164.5 & 206.3 & 170.2 & 112.8 \\
& 104.6 & 172.9 & 212.0 & 245.1 & 264.6 & 231.2 \\
\hline
\end{tabular}

Critical conditions appear in the case when the load from the superstrata is distributed up to the geometric bend point. Subsidence in such conditions above the combustion face with a gasification channel length $30 \mathrm{~m}$ will be $142 \mathrm{~mm}$ and at a length $60-209 \mathrm{~mm}$.

Maximum horizontal deformations in the layer of the main roof rocks are $6.1-7.0 \mathrm{~mm} / \mathrm{m}$. This leads to the vertical fissures developing in the roof rocks. Under the action of flexure, in the sections under consideration ( $L=25.0-30.0 \mathrm{~m}$ ), the rocks of the main roof are under the stress that affect the strength properties of the rock bed. The stresses arising at flexure in the cross sections of the rock layers are presented in Table 4.

Based on the analysis of the calculation results, the destruction of the main roof is observed only by formation, since the rock layers resistance to shearing is 3.1 $\mathrm{MPa}$, for compression - 4.6 MPa, and for breakage along the formation - 0.09 $\mathrm{MPa}$. At critical deformations (Table 3), roof collapse is not observed. In order

\section{Table 4}

Stresses arising at flexure in the cross sections of the rock layers

\begin{tabular}{|c|c|c|c|c|c|c|}
\hline \multirow{2}{*}{$\begin{array}{c}\text { Section } \\
\text { location, } \\
\mathrm{m}\end{array}$} & \multirow{2}{*}{$\begin{array}{c}\text { Shear } \\
\text { force }\end{array}$} & \multirow{2}{*}{$\begin{array}{c}\text { Moment } \\
(M),\end{array}$} & \multicolumn{4}{|c|}{ Flexure stresses, } \\
\cline { 4 - 7 } & $\mathrm{MN}$, & $G_{c}$ & $G_{r}$ & $G_{\text {от }}$ & $\tau_{\max }$ \\
\hline 22.5 & 20.6 & 356 & 1.1 & 0.07 & 0.01 & 2.3 \\
\hline 29.5 & 25.2 & 811 & 3.4 & 0.12 & 0.04 & 1.8 \\
\hline
\end{tabular}

rock layer be collapsed in the cross-section under consideration, the plastic hinge formation at total stresses at least $7.9 \mathrm{MPa}$ is required. The compressive stresses arising in the section under consideration during the layer broken condition do not exceed 3.4 MPa.

Analyzing the results of the study, it should be noted that the rock layers of the main roof, under the given conditions, will smoothly descend with the vertical fissures formation with 5 to 8 fissures intensity per 1 p.m. The main roof stratification will occur on three layers with $1.5,1.8$ and $2.3 \mathrm{~m}$ thickness.

Sandy shale, composing the bottom bench of the adjacent roof of the $c_{5}$ layer, under the influence of temperatures is prone to heave, since its composition includes a number of components: $\mathrm{SiO}_{2}-59.2, \mathrm{Al}_{2} \mathrm{O}_{3} / \mathrm{SiO}_{2}-0.19$ and $\mathrm{C}-1.07 \%$ [22]. The coefficient of roof rocks heave $\left(K_{r}\right)$ will be 1.16 . The rocks of the burned-out coal bed are mainly represented with irregular metal, which is prone to heave $\left(K_{r}=1.4\right)$. The coefficient $K_{r}$ depends on the temperatures distribution along the underground gasifier channel length. The displacements and stresses of the adjacent roof rocks $c_{5}$ layer are presented in Table 5 .

Based on the data, obtained from Table 5 it was found that under the influence of geomechanical and thermodynamic factors on the adjacent roof rocks, the maximum soil roll reached $165.8 \mathrm{~mm}$ with a gasification channel length $30 \mathrm{~m}$ and $203.8 \mathrm{~mm}$ with a channel length $60 \mathrm{~m}$, which is based on the ash-and-slag capacity (7.5-10.2 mm), almost one-third of the burned-out coal bed capacity. 
Table 5 2. Vladyko, O., Kononenko, M. and Khomenko, O.,

Displacements and stresses of adjacent roof rocks $c_{5}$ layer

\begin{tabular}{|c|c|c|c|c|c|c|}
\hline \multirow{3}{*}{ Indicator } & \multicolumn{6}{|c|}{$\begin{array}{c}\text { Distance from the coordinates to the section } \\
\text { under consideration, } \mathrm{m}\end{array}$} \\
\cline { 2 - 7 } & 5 & 10 & 15 & 20 & 25 & 30 \\
& 10 & 20 & 30 & 40 & 50 & 60 \\
\cline { 2 - 7 } & \multicolumn{7}{|c|}{ stress, MPa } \\
\hline \multirow{2}{*}{$G_{c}$} & 1.03 & 1.54 & 1.75 & 1.9 & 2.1 & 2.8 \\
& 1.26 & 1.8 & 2.2 & 2.6 & 2.9 & 3.2 \\
\hline \multirow{2}{*}{$G_{r}$} & 0.04 & 0.07 & 0.08 & 0.09 & 1.1 & 1.5 \\
& 0.06 & 0.08 & 1.0 & 1.2 & 1.4 & 1.6 \\
\hline \multirow{2}{*}{$\tau_{(\max )}$} & 1.2 & 1.7 & 2.0 & 2.5 & 2.8 & 3.1 \\
& 1.8 & 2.4 & 2.9 & 3.2 & 3.6 & 3.8 \\
\hline \multirow{2}{*}{$Y_{n}$} & \multicolumn{7}{|c|}{ roll, mm } \\
\cline { 2 - 7 } & 39.2 & 68.7 & 104.8 & 129.5 & 152.4 & 165.8 \\
& 46.5 & 72.6 & 135.1 & 152.9 & 174.7 & 203.8 \\
\hline
\end{tabular}

Conclusions. Analyzing the results of the study, we can state that the primary factor is in the anthropogenic rocks broken condition occurrence containing an underground gasifier is rock pressure. The temperature influence on the rocks, directly adjacent to the combustion face, should be considered as a secondary factor that arises in the active phase of the coal seam gasification.

It has been established that with the change in the parameters of the bearing zone and the increase in the underground gasifier half-span length, at a velocity of the combustion face advance less than $0.5 \mathrm{~m} /$ day or its stopage, the roof rocks collapse is possible directly onto the combustion face, which will destabilize thermochemical reactions zones along its length.

At the boundary of the oxidizing zone transition to the reducing zone in 14.8-16.5 m interval, at gasification channel length $30 \mathrm{~m}$, there will be no rock spalling, the same phenomena will be characteristic at gasification channel length $60 \mathrm{~m}$ in the double gasifiers transition zones. In the transition zones, sandy shale goes into a plastic state to $16-24 \mathrm{~cm}$ depth under the influence of high temperatures. When removed from the combustion face into the affected area, roof rocks cool down and smoothly fall on the heaved soil.

Taking into account the obtained data during the research, forms an engineering technique for determining the conditions of "rock massive - underground gasifier" system adaptability for predicting the stability of the process of borehole underground gasification in such mining and geological conditions.

Acknowledgements. This work was supported by the Ministry of Education and Science of Ukraine, grants No. 0116 U008041 and No. 0117 U001127.

\section{References.}

1. Falshtyns'kyy, V., Dychkovs'kyy, R., Lozyns'kyy, V. and Saik, P., 2013. Justification of the gasification channel length in underground gas generator. Annual Scientific-Technical Collection - Mining of Mineral Deposits, pp. 125-132. DOI:10.1201/b16354-23.
2012. Imitating modeling stability of mine workings. Geomechanical Processes During Underground Mining, pp. 147-150. DOI:10.1201/b13157-26.

3. Sotskov, V. and Saleev, I., 2013. Investigation of the rock massif stress strain state in conditions of the drainage drift overworking. Mining of Mineral Deposits, pp. 197-201. DOI:10.1201/b16354-36.

4. Bondarenko, V., Maksymova, E. and Koval, O., 2013. Genetic classification of gas hydrates deposits types by geologic-structural criteria. Annual Scientific-Technical Collection - Mining of Mineral Deposits, pp. 115-119. DOI:10.1201/b16354-21.

5. Dychkovskyi, R. O., Lozynskyi, V.H., Saik, P. B., Petlovanyi, M.V., Malanchuk, Ye.Z. and Malanchuk, Z. R., 2018. Modeling of the disjunctive geological fault influence on the exploitation wells stability during underground coal gasification. Archives of Civil and Mechanical Engineering, 18(3), pp. 1136-1148. DOI: 10.1016/j.acme.2018.01.012.

6. Ovchynnikov, M., Ganushevych, K. and Sai, K., 2013. Methodology of gas hydrates formation from gaseous mixtures of various compositions. Annual Scientific-Technical Collection - Mining of Mineral Deposits, pp. 203205. DOI: 10.1201/b16354-37.

7. Bondarenko, V., Svietkina, O. and Sai, K., 2017. Study of the formation mechanism of gas hydrates of methane in the presence of surface-active substances. EasternEuropean Journal of Enterprise Technologies, 5(6(89)), pp. 48-55. DOI: 10.15587/1729-4061.2017.112313.

8. Khomenko, O., Kononenko, M. and Myronova, I., 2013. Blasting works technology to decrease an emission of harmful matters into the mine atmosphere. Mining of Mineral Deposits, pp. 231-235. DOI:10.1201/b1635443.

9. Gorova, A., Pavlychenko, A., Kulyna, S. and Shkremetko, O., 2012. Ecological problems of post-industrial mining areas. Geomechanical Processes During Underground Mining, pp. 35-40. DOI: 10.1201/b13157-7.

10. Falshtynskyi, V., Dychkovskyi, R., Lozynskyi, V. and Saik, P., 2012. New method for justification of the technological parameters of coal gasification in the test setting. Geomechanical Processes During Underground Mining - Proceedings of the School of Underground Mining, pp. 201-208. DOI: 10.1201/b13157-710.1201/b13157-35. 11. Otto, C. and Kempka, T., 2015. Thermo-mechanical simulations of rock behavior in underground coal gasification show negligible impact of temperature-dependent parameters on permeability changes. Energies, 8(6), pp. 5800-5827. DOI:10.3390/en8065800.

12. Dubiński, J. and Turek, M., 2016. Mining problems of underground coal gasification - Reflections based on experience gained in experiment conducted in KHW S.A. Wieczorek coal mine. Mining Science, 23, pp. 7-20. DOI:10.1201/b13157-710.5277/msc 162301.

13. Janoszek, T., Stańczyk, K. and Smoliński, A., 2017. Modelling Test of Autothermal Gasification Process Using CFD. Archives of Mining Sciences, 62(2), pp. 253-268. DOI:10.1201/b13157-710.1515/amsc-2017-0019.

14. Cherniaiev, O. V., 2017. Systematization of the hard rock non-metallic mineral deposits for improvement of 
their mining technologies. Naukovyi Visnyk Natsionalnoho Hirnychoho Universytetu, 5, pp. 11-17.

15. Petlovanyi, M., Sai, K. and Malanchyk, Ye., 2018. Analytical Research of the Stress-Deformed State in the Rock Massif around Faulting. International Journal of Engineering Research in Africa, 35, pp. 46-57.

16. Dryzhenko, A., Moldabayev, S., Shustov, A., Adamchuk, A. and Sarybayev, N., 2017. Open pit mining technology of steeply dipping mineral occurrences by steeply inclined sublayers. International Multidisciplinary Scientific GeoConference Surveying Geology and Mining Ecology Management, SGEM, 17(13), pp. 599-606.

17. Kononenko, M., Khomenko, O., Sudakov, A., Drobot, S. and Lkhagva, Ts., 2016. Numerical modelling of massif zonal structuring around underground working. Mining of Mineral Deposits, 10(3), pp. 101-106. DOI: 10.15407/mining 10.03.101.

18. Tabachenko, M., 2016. Substantiating parameters of stratification cavities formation in the roof rocks during underground coal gasification. Mining of Mineral Deposits, 10(1), pp. 16-24. DOI:10.1201/b13157-710.15407/ mining 10.01.016.

19. Golinko, V. I., Yavorskiy, A. V., Lebedev, Ya. Ya. and Yavorskaya, Ye.A., 2014. Estimation of frictional sparking effect on firedamp inflammation during fragmentation of gas-saturated rock massif. Naukovyi Visnyk Natsionalnoho Hirnychoho Universytetu, 6, pp. 31-37.

20. Sakhno, I., Isayenkov, O. and Rodzin, S., 2017. Local reinforcing of footing supported in the destroyed rock massif. Mining of Mineral Deposits, 11(1), pp. 9-16. DOI: $10.1201 / \mathrm{b} 13157-710.15407 /$ mining11.01.009.

21. Filatiev, M., 2017. Effect of rocks displacement activation on the formation of the surface trough during anthracite seams extraction. Mining of Mineral Deposits, 11(2), pp. 91-95. DOI: 10.1201/b13157-710.15407/ mining 11.02.091.

22. Kuz'menko, O., Petlyovanyy, M. and Stupnik, M., 2013. The influence of fine particles of binding materials on the strength properties of hardening backfill. Annual Scientific-Technical Collection - Mining of Mineral Deposits, pp. 45-48. DOI: 10.1201/b13157-710.1201/b16354-10.

\section{Обгрунтування адаптивності системи „гірський масив - підземний газогенератор“ ділянки „Соленівська“ Донецького кам'яновугільного басейну}

\section{В. С. Фальштинський ${ }^{1}$, Р. О. Дичковський ${ }^{1}$, П. Б. Саїк ${ }^{1}$, В. Г. Лозинський, Е. К. Кабана}

1 - Державний вищий навчальний заклад „Національний гірничий університет“, м. Дніпро, Україна, e-mail: saik.nmu@gmail.com

2 - Науково-дослідний інститут Центру відновлювальної енергетики та енергоефективності Університету Святого Августина, Перу, e-mail: ecaceresca@unsa.edu.pe

Мета. Дослідження напружено-деформованого стану гірського масиву навколо підземного газогенератора з урахуванням зміни суцільності порід покрівлі та їі термодинамічних напружень.
Методика. Проведення аналітичних досліджень базувалося на основі прийнятої фізичної й математичної моделей, для розробки яких приймається теорія зрушення гірського масиву професора О. В. Савостьянова, що відображають особливості поведінки породної товщі над газогенератором (розшарування, утворення тріщин і порожнин розшарування, зрушення шарів відносно один одного).

Результати. Виконані багатоваріантні розрахунки напружено-деформованого стану гірського масиву навколо підземного газогенератора зі встановленням параметрів епюр навантажень на підроблювані шари масиву залежно від геологічних, технологічних і тимчасових факторів.

Наукова новизна. Встановлені залежності поширення опорних зон підземного газогенератора на рівні безпосередньої покрівлі вугільного пласта 3 урахуванням довжини реакційного каналу (30 i 60 м) і швидкості посування вогневого вибою від 0,5 до 2,0 м/доб. Уперше отримані залежності параметрів опускання породних шарів покрівлі підземного газогенератора від геомеханічних факторів, а також від показників термонапруження за довжиною реакційного каналу й швидкості посування вогневого вибою.

Практична значимість. Запропонована математична модель для визначення напружень у гірському масиві в різних його перерізах при свердловинній підземній газифікації вугілля для встановлення умов адаптивності системи „гірський масив - підземний газогенератор“ з урахуванням геомеханічних факторів і термонапружень за довжиною реакційного каналу. Отримані залежності дають можливість прогнозувати необхідну швидкість посування вогневого вибою для забезпечення технологічності процесу газифікації.

Ключові слова: підземна газифікація, вогневий вибій, гірський масив, реакційний канал, напружено-деформований стан

\section{Обоснование адаптивности системы „горный массив - подземный газогенератор“ участка „Соленовский“ Донецкого каменноугольного бассейна}

\author{
В. С. Фальштынскийㄹ, Р.Е. Дычковский ${ }^{1}$, П. Б. Саик ${ }^{1}$, \\ В. Г. Лозинский ${ }^{1}$, Е. К. Кабана \\ 1 - Государственное высшее учебное заведение „Нацио- \\ нальный горный университет“, г. Днепр, Украина, \\ e-mail: saik.nmu@gmail.com \\ 2 - Научно-исследовательский институт Центра возоб- \\ новляемой энергетики и энергоэффективности Универ- \\ ситета Святого Августина, Перу, e-mail: ecaceresca@unsa. \\ edu.pe
}

Цель. Исследование напряженно-деформированного состояния горного массива вокруг подземного газогенератора с учетом изменения сплошности пород кровли и ее термодинамических напряжений. 
Методика. Проведение аналитических исследований базировалось на основе принятой физической и математической моделей, для разработки которых принимается теория сдвижения горного массива профессора А.В. Савостьянова, отражающие особенности поведения породной толщи над газогенератором (расслоение, образование трещин и полостей расслоения, подвижки слоёв относительно друг друга).

Результаты. Выполнены многовариантные расчеты напряженно-деформированного состояния горного массива вокруг подземного газогенератора с установлением параметров эпюр нагрузок на подработанные слои массива в зависимости от геологических, технологических и временных факторов.

Научная новизна. Установлены зависимости распространения опорных зон подземного газогенератора на уровне непосредственной кровли угольного пласта с учетом длины реакционного канала (30 и 60 м) и скорости подвигания огневого забоя от 0,5 до 2,0 м/сут. Впервые получены зависимости параметров опускания породных слоев кров- ли подземного газогенератора от геомеханических факторов, а также от показателей термонапряжения по длине реакционного канала и скорости подвигания огневого забоя.

Практическая значимость. Предложена математическая модель для определения напряжений в горном массиве в различных его сечениях при скважинной подземной газификации углей для установления условий адаптивности системы „горный массив - подземный газогенератор“ с учетом геомеханических факторов и термонапряжений по длине реакционного канала. Полученные зависимости дают возможность прогнозировать необходимую скорость подвигания огневого забоя для обеспечения технологичности процесса газификации.

Ключевые слова: подземная газификация, огневой забой, горный массив, реакционный канал, напряженно-деформированное состояние

Рекомендовано до публікації докт. техн. наук I.А.Ковалевською. Дата надходження рукопису 11.05.17. 